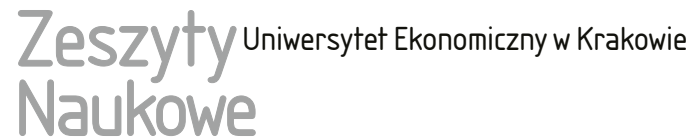

\section{Wpływ płci na postrzeganie podwładnych przez przełożonych}

\section{Streszczenie}

Celem artykułu jest wyjaśnienie wpływu płci na postrzeganie podwładnych przez przełożonych. Analizę przeprowadzono na podstawie przeglądu literatury przedmiotu oraz wyników badań opinii podwładnych na temat przełożonych przeprowadzonych w 2016 r. przez Instytut Kapitału Ludzkiego Szkoły Głównej Handlowej w Warszawie. Na podstawie źródeł literaturowych zidentyfikowane zostały przyczyny luki wynagrodzeń. Pokazano dynamikę zmian w obsadzaniu kobiet na najwyższych stanowiskach w Polsce i Unii Europejskiej. Określony został wpływ przełożonego na przebieg kariery zawodowej pracownika. Wskazano przyczyny nieefektywności programów mających na celu obiektywizację decyzji o promocji. Na podstawie wyników badań ilościowych ustalono różnice w relacjach podwładnych z przełożonymi w zależności od płci. Kluczowa rozbieżność dotyczy kwestii związanych ze sprawiedliwością, w szczególności oceny pracowników, podziału zadań i nagród.

Słowa kluczowe: luka wynagrodzeń, kobiety w zarządach, mentoring, możliwości kariery.

Klasyfikacja JEL: J16, J24, J31, J71.

Hanna Kinowska, Szkoła Główna Handlowa w Warszawie, Instytut Kapitału Ludzkiego, Zakład Zarządzania Kapitałem Ludzkim, al. Niepodległości 162, 02-554 Warszawa, e-mail: hanna.kinowska@ sgh.waw.pl 


\section{Wprowadzenie}

Zgodnie z tradycyjnym podziałem ról kobiety są odpowiedzialne za prowadzenie gospodarstwa domowego, a mężczyźni zapewniają rodzinie utrzymanie. Pomimo przemian społecznych, w tym znacznego awansu kobiet, nadal z trudem przychodzi im przełamywanie barier, jakie narzuca kultura. Pod względem poziomu wykształcenia i aspiracji obie płcie nie różnią się od siebie. Mimo że współczesnych organizacji nie stać na marnotrawienie kapitału ludzkiego, nie wykorzystują one w pełni potencjału kobiet, w szczególności na najwyższych stanowiskach. Wykorzystywanie unikalnych kompetencji powinno być wynagradzane niezależnie od płci, różnice w wynagrodzeniach pań i panów nadal się jednak utrzymują. Badacze wskazują liczne powody tego stanu rzeczy, zarówno obiektywne, takie jak doświadczenie zawodowe i przerwy w pracy z powodu macierzyństwa, jak i subiektywne, wynikające ze stereotypów dotyczących płci [Barriers and Bias... 2016].

Stereotypy dotyczące postrzegania zdolności kobiet do zajmowania stanowisk kierowniczych stanowią istotną barierę awansu [Baskiewicz 2013]. Panie są określane jako mniej asertywne oraz w mniejszym stopniu nastawione na konkurowanie. Nie mają też odpowiedniej siły przebicia [Budrowska, Duch i Titkow 2003]. Cechy charakteryzujące liderów przypisywane są mężczyznom i stanowią ich przewagę w walce o szczyty organizacji [Kupczyk 2009].

Firmy są bytami społecznymi. Awanse na najwyższe stanowiska zależą od umiejętności zbudowania odpowiednich relacji z decydentami. Możliwości kariery zależą m.in. od kontaktów z innymi osobami [Lisowska 2000], wśród których najważniejszą rolę odgrywa przełożony. Decyduje on o promocjach na początku ścieżki zawodowej pracownika, ma wpływ na rozwój kompetencji podwładnego. Menedżer aktywnie promuje najlepszych pracowników. Jego subiektywne oceny, osadzone w kontekście oczekiwań od płci, mogą wpływać na kształt i tempo kariery. Zróżnicowanie relacji z podwładnymi w zależności od ich płci, w szczególności pod wpływem stereotypów, może skutkować inną dynamiką kariery kobiet i mężczyzn.

Celem artykułu jest wyjaśnienie rozbieżności w postrzeganiu podwładnych przez przełożonych przez pryzmat płci. Różnice w relacjach, będące skutkiem innej percepcji pracowników w zależności od płci, mogą wpływać na możliwości awansowania na najwyższe stanowiska oraz dostępne poziomy wynagrodzeń kobiet i mężczyzn. Sedno różnic dotyczących kariery i wysokości płac zostało ustalone na podstawie przeglądu literatury przedmiotu. Istota odmienności działań przełożonych w stosunku do podwładnych w zależności od płci została zbadana na podstawie wyników badań opinii podwładnych na temat przełożonych przeprowadzonych w 2016 r. przez Instytut Kapitału Ludzkiego Szkoły Głównej Handlowej w Warszawie. 


\section{Luka wynagrodzeń}

Nierówności płac kobiet i mężczyzn to zagadnienie intensywnie badane w naukach społecznych. Problem ten nazywany jest luką wynagrodzeń i odnosi się do różnicy w średnich zarobkach pracowników płci męskiej i żeńskiej po uwzględnieniu czynników charakteryzujących kapitał ludzki, takich jak np. poziom wykształcenia czy doświadczenie zawodowe [Blau i Kahn 2006]. Temat różnic w wynagrodzeniach interesuje wielu naukowców. Badania prowadzone są na gruncie ekonomii, socjologii i psychologii.

Istnienie różnic w wynagrodzeniach jest niepodważalne; widać je w statystykach opisujących rynek pracy. W USA na skutek różnicy w wynagrodzeniach przeciętna kobieta musiała pracować aż do połowy kwietnia 2016 r., żeby zarobić tyle samo co mężczyzna w 2015 r. [The Simple Truth... 2016]. Podobne różnice występują w Unii Europejskiej. Przykładowo w Wielkiej Brytanii kobieta zatrudniona w pełnym wymiarze czasu pracy w ciągu życia traci ok. 369000 GBP [Khoreva 2011]. W Polsce średnie wynagrodzenie kobiet jest o $17 \%$ niższe niż przeciętne wynagrodzenie mężczyzn [Kobiety i mężczyźni... 2016].

Dostrzeżenie różnicy w wynagrodzeniach kobiet i mężczyzn niemal na całym świecie wywołało potrzebę lepszego zrozumienia czynników przyczyniających się do jej powstania [Rubery, Grimshaw i Figueiredo 2005]. Powodów poszukuje się na dwóch poziomach: makro - traktując kobiety jako jednorodną grupę, i mikro - poszukując wyjaśnień w różnicach pomiędzy pracującymi. Na poziomie makro ekonomiści starają się odnaleźć wyjaśnienia w różnicach w wykształceniu, doświadczeniu zawodowym, pensji początkowej, a także dyskryminacji [Keaveny, Inderrieden i Toumanoff 2007]. Wyjaśnienia na poziomie mikro obejmują takie czynniki, jak: indywidualne preferencje pracowników, siły kształtujące postawy wobec pracy i praktyki wynagrodzeń [Breen i Garsia-Penalosa 2002].

W ostatnich latach poczyniono znaczące postępy w wyjaśnianiu sposobu, w jaki działania organizacji przyczyniają się do nierówności w miejscu pracy [Kalev 2009]. Znacznie mniej uwagi poświęcono zrozumieniu wpływu menedżerów na kształt kariery pracowników w zależności od ich płci. Zostało potwierdzone, że menedżerowie oddziałują na podziały w miejscu pracy [Huffman, Cohen i Pearlman 2010], nierówności płac [Cohen i Huffman 2007] i dostęp do władzy [Elliott i Smith 2004]. Powyższe wnioski nie są zaskakujące z uwagi na to, że biorą oni udział w podejmowaniu decyzji o zatrudnieniu, przydzielaniu projektów, szkoleniach, awansach, podwyżkach i wypowiedzeniach [Briscoe i Kellogg 2011]. Zarządzający nierzadko podejmują również uznaniowe decyzje dotyczące wynagradzania pracowników [Manning i Swaffield 2008]. Wpływają na projektowanie i wdrażanie struktur, procesów i procedur organizacyjnych, w szczególności tych dotyczących oceny pracy [Castilla 2011]. 
Można wyróżnić kilka mechanizmów kształtujących wpływ menedżerów na wyniki oceny pracownika, które przekładają się na dystrybucję nagród i awanse. Przełożeni ustalają oceny swoich podwładnych m.in. pod wpływem innych kierowników, w szczególności tych w swojej sieci kontaktów. Menedżerowie otaczają się osobami do siebie podobnymi [McPherson, Smith-Lovin i Cook 2001]. Faworyzują je również w procesach oceny [Elastyczne zarzq̨dzanie... 2007, s. 224] i podziale nagród. Każdy z tych mechanizmów ma poważne konsekwencje dla skutków oceny wyników pracy takich jak wynagrodzenia i awanse [Zarzq̨dzanie kapitatem... 2014, s. 364].

\section{Kobiety na najwyższych stanowiskach}

Obecność kobiet na najwyższych stanowiskach menedżerskich pozytywnie wpływa na wyniki finansowe spółek. Panie są postrzegane jako bardziej otwarte na dialog z różnymi stronami sporu. Z kolei rady nadzorcze, które dopuszczają do swojego grona kobiety - co jest częstsze niż w przypadku zarządów - aktywniej i bardziej skrupulatnie wypełniają swoje obowiązki. Wyższy udział pań poprawia sprawność działania nadzoru i wyniki biznesowe [Adams i Ferreira 2009].

Rady nadzorcze i zarządy spółek, które mają w swoich szeregach kobiety, częściej przestrzegają norm etycznych, a także uważniej strzegą ładu korporacyjnego. Połączony efekt działania obu czynników ma pozytywny wpływ na wyniki finansowe.

Odsetek kobiet będących absolwentkami wyższych uczelni w Polsce jest wyższy (65\%) [Szkoły wyższe... 2016] niż średnia dla Unii Europejskiej (60\%) [Gender Balance... 2015]. Mimo to mężczyźni nadal zdecydowanie dominują na najwyższych szczeblach hierarchii firmowych.

Państwa członkowskie Unii, aby zapewnić kobietom szerszy dostęp do najwyższych stanowisk w spółkach, wprowadzają ustawy kwotowe. Przyspieszają one tempo rozwoju karier kobiet w biznesie. Nie jest to jedyny sposób oddziaływania na promowanie kobiet na najwyższe stanowiska. Wielka Brytania, Szwecja, Finlandia czy Dania nie wprowadziły ustaw kwotowych, a udział pań piastujących wysokie stanowiska w organizacji się zwiększył1

W Polsce procentowy udział kobiet w organach spółek giełdowych jest stabilny. Tabela 1 zawiera zestawienie liczebności kobiet w zarządach i radach nadzorczych. $Z$ danych wynika, że procentowy udział pań we władzach spółek wzrósł nieznacznie: z 12,09\% w 2012 r. do 13,62\% w 2015 r. Udział kobiet w grupie członków zarządu spółek na rynku głównym również zmienił się minimalnie

${ }^{1}$ Wyjątkowa sytuacja kobiet na rynku pracy w Skandynawii tłumaczona jest szczególnymi uwarunkowaniami wynikającymi m.in. z historii tych krajów [Sadowska 2006]. 
i w 2015 r. osiągnął poziom 12,05\% [Kobiety we wtadzach... 2016]. Mimo niskich wskaźników wyniki wypadają korzystnie na tle 28 krajów Unii Europejskiej. W UE dynamika zmian jest wprawdzie większa, ale udział kobiet jest mniejszy (wzrost z 3,4\% w 2012 r. do 7,1\% w 2015 r.) [Gender Balance... 2015].

Tabela 1. Liczebność zarządów i rad nadzorczych w spółkach giełdowych notowanych na rynku głównym w latach 2012-2015

\begin{tabular}{|l|c|c|c|c|}
\hline \multicolumn{1}{|c|}{ Wyszczególnienie } & 2012 & 2013 & 2014 & 2015 \\
\hline Liczba spółek & 437 & 448 & 471 & 479 \\
\hline Liczba członków zarządów, w tym: & 1298 & 1331 & 1365 & 1427 \\
\hline liczba kobiet członków zarządu & 110 & 122 & 124 & 139 \\
\hline liczba kobiet na stanowisku prezesa zarządu & 27 & 31 & 32 & 33 \\
\hline Liczba członków rad nadzorczych, w tym & 2373 & 2434 & 2550 & 2568 \\
\hline liczba kobiet członków rad nadzorczych & 235 & 243 & 252 & 287 \\
\hline
\end{tabular}

Źródło: [Kobiety we władzach... 2016].

W 2015 r. w Polsce 6,89\% prezesów zarządów spółek giełdowych rynku głównego stanowiły kobiety (ich udział wzrósł w porównaniu z 6,18\% w 2012 r.) [Kobiety we władzach... 2016]. Dynamika zmian w Unii była podobna. Przeciętny udział kobiet na stanowisku prezesa zarządu w spółkach giełdowych w 28 krajach członkowskich w tym samym przedziale czasowym wzrósł z 3,0\% do 3,6\% [Gender Balance... 2015].

W przypadku organów nadzorczych również można zauważyć tendencję wzrostową dotyczącą udziału kobiet. Wskaźnik dla rynku głównego wzrósł z 12,94\% w 2012 r. do 14,49\% w 2015 r. Udział kobiet, którym w latach 2012-2015 powierzono mandat przewodniczącej rady nadzorczej, w odniesieniu do ogólnej liczby przewodniczących rad nadzorczych spółek giełdowych wynosił od 6,86\% do 9,60\% [Kobiety we władzach... 2016].

\section{Przyczyny zróżnicowania wynagrodzeń i tempa awansów kobiet i mężczyzn}

Mimo że kobiety stanowią znaczącą część kapitału ludzkiego obecnego na rynku pracy, ciągle otrzymują niższe pensje. W październiku 2014 r. średnie miesięczne wynagrodzenie kobiet w Polsce było o 764 PLN niższe niż mężczyzn.

Różnice w wynagrodzeniach kobiet i mężczyzn dla poszczególnych grup zawodowych zostały przedstawione są na rys. 1 . W każdej grupie mężczyźni zarabiali więcej. Największe różnice odnotowano wśród osób najlepiej zarabiających. 
Średnie wynagrodzenie $10 \%$ najlepiej zarabiających kobiet stanowiło zaledwie $77 \%$ średniego wynagrodzenia najlepiej zarabiających mężczyzn.

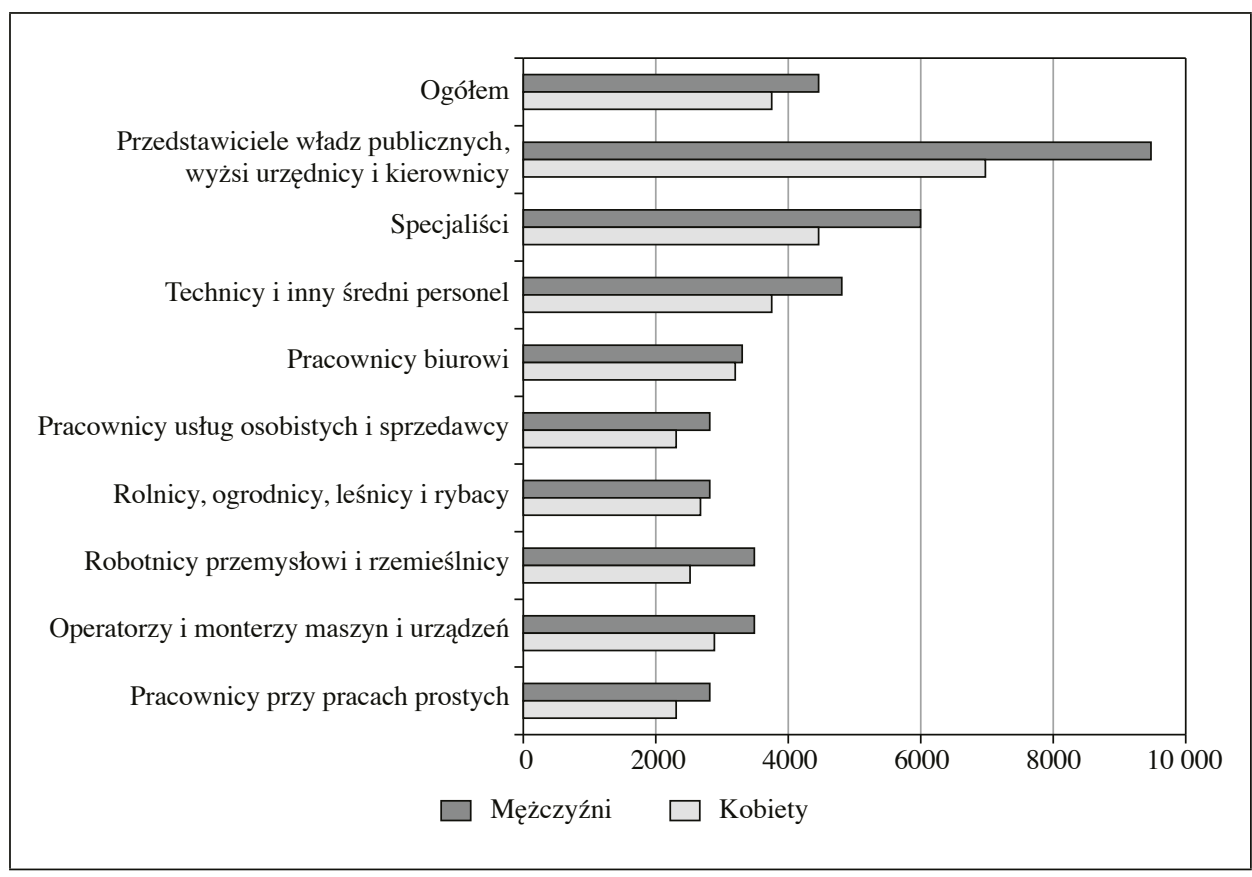

Rys. 1. Wynagrodzenie miesięczne brutto według płci i grup zawodowych w październiku 2014 r. (w PLN)

Źródło: [Kobiety i mężczyźni... 2016].

Nie istnieje jedna determinanta luki wynagrodzeń. Część kobiet zarabia mniej na skutek swoich indywidualnych wyborów życiowych, inne są ofiarami dyskryminacji. Ważnym powodem niższych pensji jest różnica w wykształceniu i doświadczeniu zawodowym pomiędzy obiema płciami. W celu przeciwdziałania różnicowaniu zarobków w zależności od płci konieczne jest podjęcie skoordynowanych działań w kilku obszarach jednocześnie.

Wykształcenie oraz doświadczenie wpływają na szanse znalezienia dobrze płatnej pracy i późniejszy awans. W Polsce pracujące kobiety najczęściej posiadają wykształcenie wyższe (42,3\% kobiet pracujących), a następnie policealne i średnie zawodowe (25,7\%) [Kobiety i mężczyźni... 2016]. Wśród pracujących mężczyzn dominują osoby z wykształceniem zasadniczym zawodowym $(32,1 \%)$, a następne w kolejności są policealne i średnie zawodowe $(27,8 \%)$ [Kobiety i mężczyźni... 2016]. Poprawa wykształcenia jest dobrą podstawą do wzrostu wynagrodzenia. Pracujące kobiety są lepiej wykształcone od mężczyzn. Argument dotyczący 
braków w wiedzy formalnej powinien tracić na znaczeniu. Podobnie jak wykształcenie silną determinantę wysokości zarobków stanowi także indywidualne doświadczenie zawodowe. Dawniej kobiety przerywały swoją karierę po ślubie lub urodzeniu dzieci. Obecnie matki z małymi dziećmi nie opuszczają rynku pracy. Wzrost doświadczenia zawodowego pań i fakt, że stanowią już niemal połowę siły roboczej, oraz utrzymywanie się luki wynagradzania każą domniemywać, że oba czynniki nie były jedynymi wpływającymi na różnicę w wysokości zarobków kobiet i mężczyzn.

Wraz z poprawą poziomu wykształcenia i doświadczenia zawodowego kobiet otworzyły się przed nimi możliwości obejmowania stanowisk, które były do tej pory zdominowane przez mężczyzn. Zjawisko to zostało nazwane cichą rewolucją [Goldin 2006]. Sam fakt szerszego dopuszczenia kobiet do „męskich” zawodów nie zmienił jednak ogólnego obrazu rynku pracy. Obszary gospodarki o najwyższej średniej zarobków, takie jak usługi teleinformatyczne czy budownictwo, nadal są zdominowane przez mężczyzn.

Z badań wynika, że posiadany zawód i sektor zatrudnienia wyjaśniają tylko część obecnej luki w wynagrodzeniach. Dwie trzecie rozbieżności w zarobkach jest niezależna od: wieku, rasy, wyznania, wykształcenia, zdobytego doświadczenia, zajmowanego stanowiska czy sektora gospodarki. Za pozostałą jedną trzecią odpowiadają dyskryminacja oraz wybory indywidualne [Blau i Kahn 2006]. Oba czynniki są trudne do zmierzenia i mają nieostre definicje, co utrudnia ich badanie.

Szczególnie trudna do zbadania jest kwestia dyskryminacji. Zaczyna się ona na długo przed wejściem na rynek pracy. Według raportu OECD [The ABC of Gender... 2015] uczennice szkół średnich, które osiągają dobre oceny z przedmiotów ścisłych, charakteryzują się niskim poziomem pewności własnych kompetencji i samooceny swoich zdolności. Na skutek tego nie podejmują studiów na kierunkach technicznych. Nawet gdy kobietom uda się zdobyć ścisłe wykształcenie i znaleźć zatrudnienie zgodne z kierunkiem studiów, połowa z nich kończy karierę znacznie szybciej niż mężczyźni. Odchodząc z pracy, kobiety skarżą się na kulturę „macho”, wrogość otoczenia i brak dopasowania [Gender Pay Gap... 2015]. Narracja pań, które spróbowały sił w „męskich” zawodach, może zniechęcać kolejne kobiety do studiowania i podejmowania pracy w wysoko wynagradzanych sektorach technicznych.

Kolejną przyczyną rozbieżności w zarobkach między płciami jest wypełnianie obowiązków rodzinnych. Mediana wieku urodzenia pierwszego dziecka cały czas rośnie i wynosi w Polsce 27 lat [Małżeństwa oraz dzietność... 2016]. Urodzeniu dziecka towarzyszy najczęściej przerwa w pracy, dlatego kobiety odkładają decyzję o macierzyństwie na później. Skupiają się na rozwijaniu swojej kariery. Jest to decyzja, która pozytywnie wpływa na zmniejszenie rozbieżności wyna- 
grodzeń pomiędzy płciami i na wysokość zarobków pań. Badania pokazują, że każdy rok opóźnienia porodu dziecka zwiększa o 9\% sumę zarobków całego życia [Miller 2011].

Posiadanie dziecka ma duży wpływ na przebieg kariery. W wieku przypadającym na wychowywanie potomstwa mężczyźni odnotowują wzrost zarobków. W tym samym czasie kobiety mierzą się z siłami wypychającymi je z rynku, skutkującymi powiększeniem się luki w wynagrodzeniach. Przykładem negatywnego wpływu decyzji o posiadaniu dziecka na zarobki kobiet są różnice w wynagrodzeniach absolwentów szkół MBA. W pierwszej zaproponowanej po studiach pracy poziom zarobków obu płci jest zbliżony. Dekadę później pensje mężczyzn są już 60\% wyższe [Bertrand, Goldin i Katz 2010]. Szybki wzrost luki występował również wśród prawników [Goldin 2014]. Po 15 latach praktyki zarobki mężczyzn były o 55\% wyższe niż kobiet. Co ciekawe, gdy uwzględniono różnice w liczbie przepracowanych godzin, zajmowanych stanowiskach i ilości czasu spędzonego poza pracą z powodu opieki nad dziećmi i rodziną, wynagrodzenie kobiet było nadal o 13\% niższe. Wniosek, że luka w wynagradzaniu obu płci nie da się wytłumaczyć wyłącznie czynnikami obiektywnymi, jak doświadczenie, czas spędzony w pracy czy stanowisko, wydaje się zasadny.

Wyjaśnień rozbieżności w zarobkach kobiet i mężczyzn poszukuje się również w przebiegu kariery zawodowej. Zależy ona m.in. od potencjału konkretnej osoby i możliwości wykorzystania swoich kompetencji w miejscu pracy. Młodzi ludzie, niezależnie od płci, na początku kariery otrzymują podobne wynagrodzenia. Następnie w zależności od wsparcia menedżera, organizacji i własnych aspiracji rozwijają karierę zawodową.

Część nierówności w dochodach kobiet i mężczyzn wynika z zasad ustalania wynagrodzeń, w szczególności uznaniowości, która wiąże się z koniecznością negocjowania podwyżek i awansów. Negocjacje zarobków mają duży potencjał dyskryminacyjny. Wychodzenie z inicjatywą i stawianie żądań płacowych przez kobiety jest postrzegane negatywnie, nawet gdy mają one opinię osób kompetentnych. W literaturze przedmiotu można znaleźć koncepcję karania za bycie aktywnym. Jednocześnie panie, które nie zgłaszają się po wyższe uposażenie czy posadę, nie otrzymują ich. Wraz z podjęciem negocjacji ryzykują swoją obecną pozycję w firmie [Bowles, Babcock i Lai 2007].

Nawet jasne i transparentne zasady awansów nie eliminują całkowicie wpływu uprzedzeń, ponieważ część z nich jest podświadoma. Dyskryminację trudno uchwycić w świecie realnym, ale liczne eksperymenty świadczą o jej obecności. Przejawia się ona w stronniczym doborze CV [Steinpreis, Anders i Ritzke 1999], w przebiegu rozmów rekrutacyjnych [Moss-Racusin i in. 2012]. Tendencyjność i subiektywizm oceniającego przekładają się na poziom stanowiska i pensji kandydatki lub kandydata i mogą oddziaływać na całą karierę w firmie. 


\section{Relacje z menedżerami i możliwości rozwoju kariery}

Badania potwierdzają wpływ relacji społecznych na funkcjonowanie w miejscu pracy [Ibarra i Andrews 1993]. Oddziałują one na zatrudnianie, awanse [Petersen, Saporta i Seidel 2000, Yakubovich 2005], produktywność i fluktuację pracowników [Yakubovich i Lup 2006]. Opinia kadry menedżerskiej wyższego szczebla o wynikach i potencjale osoby kształtuje jej możliwości awansu. Reputacja pracownika upowszechnia się w organizacji m.in. dzięki sieci kontaktów menedżera.

Przełożony kształtuje swoją opinię o podwładnym na podstawie bezpośrednich doświadczeń ze współpracy z nim oraz pod wpływem relacji z innymi. Dzięki formalnym i nieformalnym interakcjom menedżerowie wymieniają między sobą opinie o pracownikach. Wpływ innych kierowników może być intencjonalny lub wynikać z przypadkowych kontaktów, wymiany historii, wiadomości, anegdot i plotek. Współpracujący ze sobą menedżerowie dzielą się informacjami o szczególnych osiągnięciach swoich pracowników. Podają przykłady potwierdzające ich spostrzeżenia i dyskutują o wyzwaniach menedżerskich, przekazują informacje o osobach sprawiających problemy. Postrzeganie pracownika przez przełożonego kształtują również wyniki ewaluacji przeprowadzone przez wcześniejszych menedżerów. Oceniający formułują opinie pod wpływem klisz i stereotypów [Duch-Krzysztoszek i Sarata 2007]. Płeć determinuje percepcję i ocenę wyników pracy. W podobnych okolicznościach biznesowych cechy postrzegane u mężczyzn jako pozytywne i gwarantujące sukces w przyszłości stanowią wady kobiet [The Double-bind Dilemma... 2007]. W konsekwencji mogą pojawiać się nierówności w ocenie i podziale nagród.

W interesie organizacji jest wykorzystywanie kapitału ludzkiego, którym dysponuje. Nieobiektywne oceny i opinie o pracownikach wpływają na pomijanie przy awansach osób o ponadprzeciętnych kompetencjach. Firmy deklarują, że są zainteresowane aktywnym wspieraniem i promowaniem utalentowanych pracowników, w szczególności kobiet, w drodze na najwyższy szczebel firmowej hierarchii. Spośród przedstawicieli korporacji przebadanych na potrzeby raportu Światowego Forum Ekonomicznego aż 59\% twierdziło, że organizacja posiada wewnętrzne programy mentorskie i networkingowe, a 28\% dodawało, że buduje je specjalnie dla kobiet [The Corporate Gender... 2010].

Kluczową rolę w promowaniu pracownika odgrywa przełożony oraz kadra menedżerska wyższego szczebla. Aby ograniczyć ryzyko pominięcia utalentowanej osoby z powodu wąskiej sieci kontaktów jej szefa, firmy stwarzają okoliczności umożliwiające zbudowanie właściwych relacji z szerszym gronem wyższej kadry kierowniczej. W celu ułatwienia pracownikom kształtowania wizerunku umożliwiającego awans na najwyższe stanowisko wdrażane są programy mentoringowe. Polegają na wyselekcjonowaniu najbardziej obiecujących mene- 
dżerów, a następnie przygotowaniu ich do objęcia wyższych stanowisk. Mimo że z programów częściej korzystają kobiety, nadal są one rzadziej awansowane na wyższe szczeble organizacji [The Myth of the Ideal... 2011], mniej zarabiają i czerpią mniejszą satysfakcję z pracy [Carter i Silva 2010].

Skuteczne zaistnienie w sieci kontaktów wymaga wsparcia wpływowego mentora. Tymczasem prezesi i członkowie zarządu częściej są mentorami mężczyzn niż kobiet (odpowiednio 78\% i 69\%). Panie wspierane są częściej przez osoby będące niżej od nich w hierarchii spółki [Ibarra, Carter i Silva 2010]. Mentorzy zajmujący podobne stanowisko do wspieranych osób ograniczają się do pomocy emocjonalnej, udzielania porad czy bycia wzorem do naśladowania. Współpraca z osobą na równoległym stanowisku ma małe przełożenie na szybki awans w ramach organizacji.

Badania wskazują, że menedżerowie niezależnie od płci czerpią więcej satysfakcji z pracy z mentorami, ale tak naprawdę dla lepszego rozwoju kariery potrzebują sponsorów [Kram i Chandler 2010]. Z ich pomocą zmniejsza się ryzyko bycia pominiętym $w$ trakcie nominacji oraz pozostanie wiecznym, dobrze zapowiadającym się menedżerem średniego szczebla z dużym potencjałem [Ibarra, Carter i Silva 2010]. Skuteczni sponsorzy zatrudnieni są na najwyższych stanowiskach w organizacji i skupiają się na aktywnym promowaniu podopiecznych. Tworzą okoliczności konfrontowania protegowanego z dyrektorami zarządzającymi, którzy mogą pomóc w dalszej karierze; walczą o jego awans. Aktywne wsparcie wyżej postawionego sponsora daje szansę na łatwiejsze wejście do grona dyrektorów zarządzających.

Zanim pracownik otrzyma możliwość uczestniczenia w programie mentorskim lub sponsorskim, dzięki któremu będzie mógł rozwijać kompetencje i zyska kontakty niezbędne do objęcia wysokich stanowisk, musi polegać na informacjach zwrotnych i wsparciu w rozwoju kariery od swojego bezpośredniego przełożonego.

Oceniając wyniki i potencjał pracownika, menedżer narażony jest na błędy oceny. Utrudniają one sformułowanie obiektywnych opinii o pracy podwładnego. Na różnicowanie ocen z powodu płci wpływa błąd podobieństwa skutkujący lepszym postrzeganiem osób mniej różniących się od oceniającego. Menedżerowie budują sieci kontaktów z osobami o zbliżonych parametrach demograficznych [Płeć a możliwości... 2004]. Podobnym do siebie chętniej ufają [McPherson, Smith-Lovin i Cook 2001]. W swoich sieciach w zbliżony sposób oceniają osiągnięcia pracowników i podejmują decyzje. Podobieństwo pracownika do przełożonego może skutkować lepszymi ocenami, a podobni do siebie menedżerowie upowszechnią je w organizacji. Łatwiej wejdą w rolę sponsorów promujących w firmie efekty pracy określonej osoby. 
Pomimo prób obiektywizacji procesu podejmowania decyzji personalnych przełożeni formułujący oceny pozostają pod wpływem stereotypów [Gorman i Kmec 2009]. Wpływają one na relacje w środowisku pracy, w szczególności na postrzeganie potencjału pracowników. Ponadto cechy charakteru, które pomagają mężczyznom na najwyższych stanowiskach, nie mogą być w prosty sposób zinternalizowane przez kobiety. W przypadku pań mogą negatywnie wpłynąć na ich postrzeganie $\mathrm{i}$ - paradoksalnie - utrudnić im awans na najwyższe stanowiska. W raporcie Catalysta wskazane są następujące paradoksy w postrzeganiu kobiet w biznesie utrudniające im awans na wyższe stanowiska [The Double-bind Dilemma... 2007]:

- kobiety są albo zbyt łagodne, albo zbyt twarde, nigdy nie są w sam raz - jeśli panie zachowują się zgodnie ze stereotypem związanym z płcią, są postrzegane jako mniej kompetentne (zbyt łagodne), gdy zaś ich postępowanie odbiega od kobiecej „normy”, są określane jako zbyt twarde;

- od kobiet oczekuje się wyższych standardów niż od mężczyzn, ale niżej się je wynagradza (nie tylko materialnie, ale też przez zaszczyty i awanse); panie muszą za każdym razem udowadniać swoje zdolności przywódcze;

- liderki mogą być albo osobami lubianymi, albo profesjonalistkami - nigdy nie mogą być jednymi i drugimi jednocześnie; kobiety wykazujące cechy przypisywane przywódcom (np. asertywność) zyskują poważanie, ale nie darzy się ich sympatią, z kolei kobiety postępujące według stereotypów płciowych nie są cenione jako skuteczne menedżerki.

\section{Różnice w postrzeganiu przełożonych przez kobiety i mężczyzn - wyniki badań}

Celem badań zrealizowanych przez Instytut Kapitału Ludzkiego Szkoły Głównej Handlowej w Warszawie było poznanie opinii podwładnych na temat ich przełożonych w obszarach objętych ankietą. Badania przeprowadzono w dniach 7-16 października 2016 r. metodą CAWI na próbie 800 respondentów aktywnych zawodowo. Reprezentatywność pracujących polskich internautów została osiągnięta za pomocą dobru próby schematem losowo-kwotowym przy kontroli takich zmiennych, jak: płeć, wiek, wykształcenie oraz wielkość miejscowości zamieszkania. Strukturę próby badawczej przedstawiono w tabeli 2.

Ankieta składała się z 59 pytań dotyczących opinii o wielu aspektach pracy przełożonych, w szczególności: wyznaczania celów, podejmowania decyzji, informacji zwrotnych, budowania sieci kontaktów, oceny pracowników, podziału nagród, delegowania uprawnień, komunikacji, rozwoju pracowników, dbania o atmosferę w zespole. Poziom istotności dla testów różnic wynosił 0,05. 
Tabela 2. Struktura próby badawczej

\begin{tabular}{|c|c|}
\hline Wyszczególnienie & Procent respondentów \\
\hline \multicolumn{2}{|l|}{ Płeć } \\
\hline kobieta & 50,5 \\
\hline mężczyzna & 49,5 \\
\hline \multicolumn{2}{|l|}{ Wiek } \\
\hline poniżej 25 lat & 8,9 \\
\hline 26-35 lat & 24,3 \\
\hline $36-45$ lat & 21,6 \\
\hline 46-55 lat & 19,6 \\
\hline powyżej 55 lat & 25,6 \\
\hline \multicolumn{2}{|l|}{ Zajmowane stanowisko } \\
\hline wykonawcze & 22,7 \\
\hline specjalistyczne & 53,0 \\
\hline kierownicze & 15,9 \\
\hline brak danych & 8,4 \\
\hline \multicolumn{2}{|l|}{ Wykształcenie } \\
\hline podstawowe/zawodowe & 5,0 \\
\hline średnie & 30,0 \\
\hline wyższe & 65,0 \\
\hline \multicolumn{2}{|l|}{ Stanowisko } \\
\hline kierownicze & 16,6 \\
\hline niekierownicze & 78,5 \\
\hline właściciel & 4,9 \\
\hline \multicolumn{2}{|l|}{ Sektor } \\
\hline prywatny & 54,6 \\
\hline publiczny & 43,3 \\
\hline inny & 2,1 \\
\hline \multicolumn{2}{|l|}{ Wielkość firmy } \\
\hline mikrofirma & 14,8 \\
\hline mała firma & 27,1 \\
\hline średnia firma & 26,9 \\
\hline duża firma & 31,3 \\
\hline \multicolumn{2}{|l|}{ Staż pracy } \\
\hline do jednego roku & 4,0 \\
\hline $1-5$ lat & 15,1 \\
\hline $6-10$ lat & 15,1 \\
\hline
\end{tabular}


cd. tabeli 2

\begin{tabular}{|l|c|}
\hline \multicolumn{1}{|c|}{ Wyszczególnienie } & Procent respondentów \\
\hline 11-15 lat & 10,8 \\
\hline 16-20 lat & 9,3 \\
\hline $21-25$ lat & 9,9 \\
\hline 26-30 lat & 9,8 \\
\hline powyżej 30 lat & 25,8 \\
\hline
\end{tabular}

Źródło: opracowanie własne na podstawie badań dotyczących opinii podwładnych na temat ich przełożonych.

Na potrzeby niniejszego artykułu przeanalizowane zostały różnice w odpowiedziach udzielonych przez kobiety i mężczyzn, dotyczące zarówno odpowiedzi twierdzących, jak i przeczących. W przypadku odpowiedzi na 12 spośród 59 pytań różnice były istotne statystycznie (zob. rys. 2).

Największe różnice pomiędzy kobietami i mężczyznami dotyczyły percepcji sprawiedliwego oceniania przez przełożonego. Kobiety częściej niż mężczyźni (różnica 13 pkt proc.) uważają, że ich przełożony nie ocenia pracowników sprawiedliwie. Mężczyźni częściej stwierdzają (różnica 10 pkt proc.), że są sprawiedliwie oceniani. Z analizy literatury przedmiotu przedstawionej we wcześniejszych częściach artykułu wynika, że przełożony ma istotny wpływ na karierę pracowników. Różnice w ocenianiu kobiet i mężczyzn mogą przekładać się na ich tempo awansów, podwyżki oraz możliwości rozwoju kompetencji. W długim okresie mogą być przyczyną utrzymywania się luki wynagrodzeń i mniejszej liczby kobiet na wyższych stanowiskach.

Kolejne pytania dotyczyły sprawiedliwego podziału zadań pomiędzy pracowników oraz podziału nagród i premii (odnotowano istotną różnicę w odpowiedziach kobiet i mężczyzn). W badaniach zadano w sumie trzy pytania dotyczące sprawiedliwości w działaniach menedżera. W przypadku każdego z nich różnice w odpowiedziach kobiet i mężczyzn były istotne statystycznie. Kobiety bardziej krytycznie oceniały sprawiedliwe postępowanie swoich przełożonych. Negatywnych odpowiedzi na wszystkie pytania o sprawiedliwość udzieliła istotnie większa liczba kobiet niż mężczyzn.

Można zauważyć logiczne związki pomiędzy poszczególnymi aspektami pracy przełożonego różnie ocenionymi przez kobiety i mężczyzn. Kobiety były bardziej krytyczne w kwestiach oceny pracy. Brak sprawiedliwej oceny oznacza m.in. nieznajomość mocnych stron pracownika - istotnie mniej kobiet niż mężczyzn uważa, że przełożony zna ich atuty. Gorsza jakość oceny skutkuje mniej sprawiedliwym podziałem nagród. Przełożony, który nie zna mocnych strony pracownika, nie dysponuje obiektywnymi informacjami pozwalającymi na sprawiedliwy 


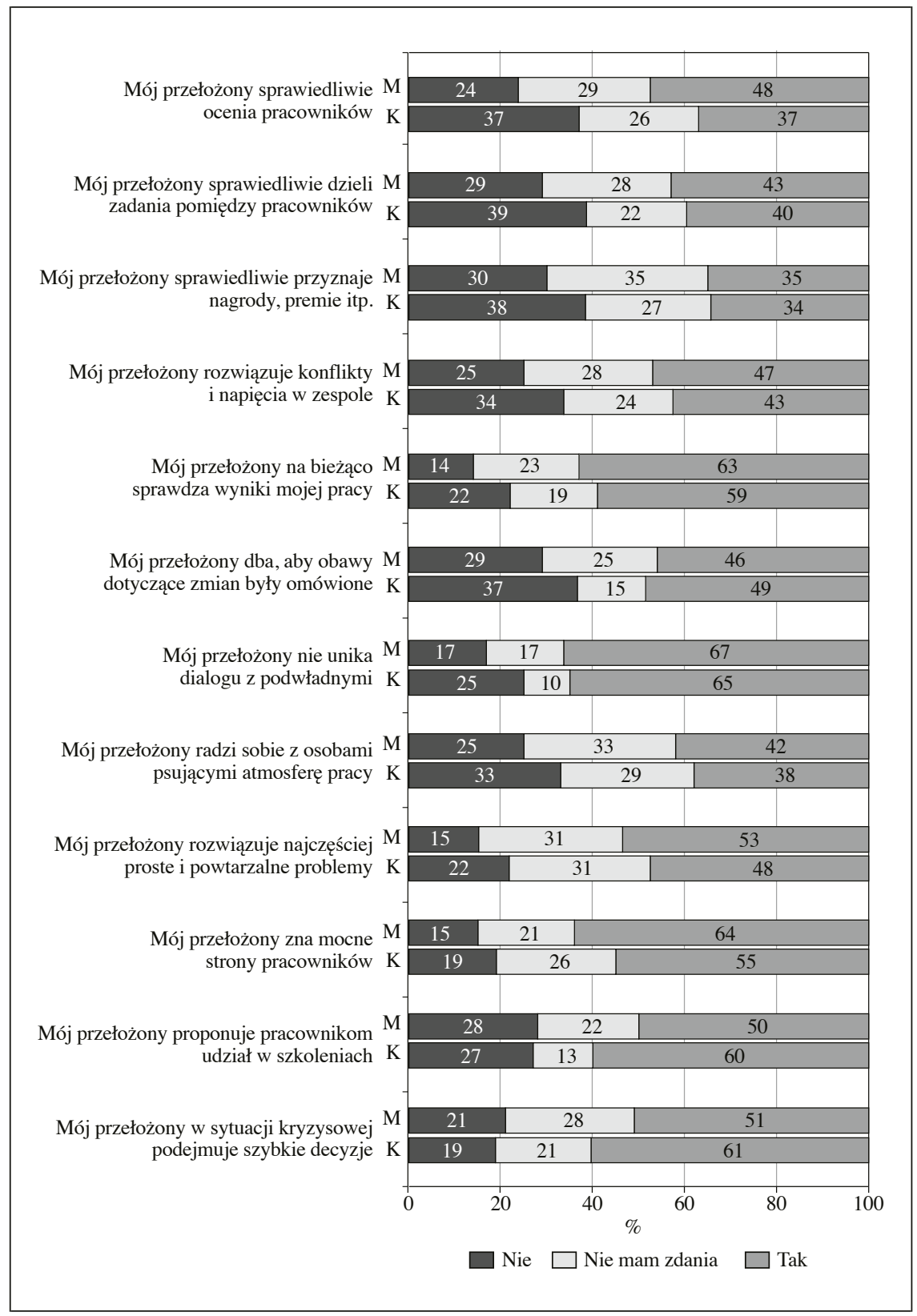

Uwagi: M - mężczyźni, K - kobiety. Rozkład odpowiedzi w postaci procentowej z zaokrągleniem do jedności.

Rys. 2. Różnice w opiniach kobiet i mężczyzn na temat przełożonych Źródło: opracowanie własne. 
podział zadań. Brak wystarczających informacji może skutkować skierowaniem pracowników na niewłaściwe szkolenia. Istotnie więcej kobiet niż mężczyzn deklaruje, że przełożony proponuje im szkolenia.

Kobiety były istotnie bardziej krytyczne niż mężczyźni również w takich obszarach jak rozwiązywanie konfliktów i radzenie sobie z osobami psującymi atmosferę w pracy. Ponadto kobiety częściej deklarowały, że ich przełożeni kontrolują wyniki pracy, unikają dialogu z podwładnymi oraz rzadziej dbają o omówienie obaw dotyczących zmian.

Spore różnice dotyczące sprawiedliwości oceny między kobietami i mężczyznami mogą być sygnałem braku umiejętności rzetelnej ewaluacji wyników pracy kobiet. W wielu firmach oceny są podstawą podziału nagród, dlatego nie jest zaskoczeniem, że odpowiedzi na pytanie o sprawiedliwość nagród również się różnią. Rozbieżności w postrzeganiu sprawiedliwości mogą być skutkiem dostrzegania przez kobiety wpływu stereotypów na percepcję przełożonych. Pilotażowy charakter badań nie pozwolił na empiryczną weryfikację hipotez dotyczących związków przyczynowo-skutkowych. Ze względu na znaczenie zgłaszanego przez kobiety problemu sprawiedliwej oceny dla kwestii zamykania luki wynagrodzeń oraz ich możliwości awansów na wyższe stanowiska wydaje się zasadne przeprowadzenie pogłębionych badań nad zróżnicowaniem relacji menedżerów z podwładnymi w zależności od ich płci.

\section{Podsumowanie}

Tematyka luki wynagrodzeń i dostępu kobiet do najwyższych stanowisk jest szeroko omawiana w literaturze przedmiotu. Badacze starają się wyjaśnić przyczyny niższych zarobków kobiet oraz ich mniejszego udziału w najwyższej kadrze menedżerskiej. Po usunięciu obiektywnych powodów, takich jak wykształcenie, doświadczenie i czas pracy, pozostaje niewyjaśniona luka. Naukowcy skłaniają się ku opinii, że jest ona skutkiem stereotypów. Na likwidację różnic w zarobkach wpływać może kształt kariery zawodowej. Na tempo awansu kluczowy wpływ ma przełożony formułujący oceny, na podstawie których podejmowane są decyzje o promowaniu podwładnego. Stereotypy dotyczące płci powodują, że oceny stają się niesprawiedliwe.

Rosnące wymogi otoczenia biznesowego wymagają od organizacji racjonalnego korzystania z kapitału ludzkiego, który mają do dyspozycji. Nie wolno im marnować potencjału z powodu uprzedzeń i błędów oceny. Złożoność zjawiska wymaga kompleksowego instrumentarium obejmującego: skupienie uwagi menedżerów na znaczeniu obiektywnej oceny pracowniczej, rozwój umiejętności przekazywania informacji zwrotnych, świadomość błędów i znajomość sposobów ich 
unikania, kształtowanie nawyków pozwalających dostrzec efekty pracy osób innej płci, a także systemowe rozwiązania umożliwiające wywieranie wpływu przez innych menedżerów na rozwój kariery pracowników, szczególnie narażonych na błędy oceny przełożonych.

\section{Literatura}

The ABC of Gender Equality in Education. Aptitude, Behaviour, Confidence [2015], OECD Publishing, http://dx.doi.org/10.1787/9789264229945-en.

Adams R., Ferreira D. [2009], Women in the Board Room and Their Impact on Governance and Performance, ,Journal of Financial Economics”, vol. 94, nr 2, https://doi.org/ 10.1016/j.jfineco.2008.10.007.

Barriers and Bias. The Status of Women in Leadership [2016], American Association of University Women, http://www.ncgs.org/Pdfs/Resources/barriers-and-bias.pdf (data dostępu: 30.01.2017).

Baskiewicz N. [2013], Kobiety w zarzqdzaniu organizacjami, „Studia Ekonomiczne. Zeszyty Naukowe Uniwersytetu Ekonomicznego w Katowicach”, nr 161.

Bertrand M., Goldin C., Katz L.F. [2010], Dynamics of the Gender Gap for Young Professionals in the Financial and Corporate Sectors, „American Economic Journal: Applied Economics", vol. 2, nr 3, https://doi.org/10.1257/app.2.3.228.

Blau F., Kahn L. [2006], The US Gender Pay Gap in the 1990s: Slowing Convergence, „Industrial and Labor Relations Review”, vol. 60, nr 1, https://doi.org/ $10.1177 / 001979390606000103$.

Bowles H.R., Babcock L., Lai L. [2007], Social Incentives for Gender Differences in the Propensity to Initiate Negotiations: Sometimes It Does Hurt to Ask, „Organizational Behavior and Human Decision Processes” 2007, vol. 103, nr 1, https://doi.org/10.1016/j. obhdp.2006.09.001.

Breen R., Garsia-Penalosa C. [2002], Learning and Gender Segregation, „Journal of Labour Economics", vol. 20, nr 4.

Briscoe F., Kellogg K.C. [2011], The Initial Assignment Effect: Local Employer Practices and Positive Career Outcomes for Work-family Program Users, „American Sociological Review", vol. 76, nr 2, https://doi.org/10.1177/0003122411401250.

Budrowska B., Duch D., Titkow A. [2003], Szklany sufit: bariery i ograniczenia karier polskich kobiet. Raport z badań jakościowych, Instytut Spraw Publicznych, Warszawa.

Carter N.M., Silva Ch. [2010], Women in Management: Delusions of Progress, „Harvard Business Review", nr 03.

Castilla E.J. [2011], Bringing Managers Back In: Managerial Influences on Workplace Inequality, „American Sociological Review”, vol. 76, nr 5, https://doi.org/ 10.1177/0003122411420814.

Cohen P.N., Huffman M.L. [2007], Working for the Woman? Female Managers and the Gender Wage Gap, „American Sociological Review”, vol. 72, nr 5, https://doi.org/ 10.1177/000312240707200502.

The Corporate Gender Gap Report 2010 [2010], World Economic Forum, http://www3. weforum.org/docs/WEF_GenderGap_CorporateReport_2010.pdf (data dostępu: 30.01.2017). 
The Double-bind Dilemma for Women in Leadership: Damned if You Do, Doomed if You Don't [2007], Catalyst, http://www.catalyst.org/system/files/The_Double_Bind_ Dilemma_for_Women_in_Leadership_Damned_if_You_Do_Doomed_if_You_Dont. pdf (data dostępu: 30.01.2017).

Duch-Krzysztoszek D., Sarata N. [2007], Praca [w:] Polityka równości płci. Polska 2007, red. B. Chołuj, Program Narodów Zjednoczonych ds. Rozwoju, Warszawa.

Elastyczne zarzqdzanie kapitałem ludzkim w organizacji wiedzy [2007], red. M. Juchnowicz, Difin, Warszawa.

Elliott J.R., Smith R.A. [2004], Race, Gender, and Workplace Power, „American Sociological Review", vol. 69, nr 3, https://doi.org/10.1177/000312240406900303.

Gender Balance on Corporate Boards. Europe Is Cracking the Glass Ceiling [2015], Komisja Europejska, http://ec.europa.eu/justice/gender-equality/files/womenonboards/ factsheet_women_on_boards_web_2015-10_en.pdf (data dostępu: 29.01.2017).

Gender Pay Gap: Recent Trends and Explanations [2015], Council of Economic Advisers, White House.

Goldin C. [2006], The Quiet Revolution That Transformed Women's Employment, Education, and Family, ,American Economic Review”, vol. 96, nr 2, https://doi.org/ 10.1257/000282806777212350.

Goldin C. [2014], A Grand Gender Convergence: Its Last Chapter, „American Economic Review", vol. 104, nr 4, https://doi.org/10.1257/aer.104.4.1091.

Gorman E., Kmec J.A. [2009], Hierarchical Rank and Women's Organizational Mobility: Glass Ceilings in Corporate Law Firms, „American Journal of Sociology”, vol. 114, nr 5, https://doi.org/10.1086/595950.

Huffman M.L., Cohen P.N., Pearlman J. [2010], Engendering Change: Organizational Dynamics and Workplace Gender Desegregation, 1975-2005, „Administrative Science Quarterly", vol. 55, nr 2, https://doi.org/10.2189/asqu.2010.55.2.255.

Ibarra H., Andrews S.B. [1993], Power, Social Influence, and Sense Making: Effects of Network Centrality and Proximity on Employee Perceptions, ,Administrative Science Quarterly", vol. 38, nr 2, https://doi.org/10.2307/2393414.

Ibarra H., Carter N.M., Silva Ch. [2010], Why Men Still Get More Promotions Than Women, „Harvard Business Review”, nr 10.

Kalev A. [2009], Cracking the Glass Cages? Restructuring and Ascriptive Inequality at Work, ,American Journal of Sociology”, vol. 114, nr 6, https://doi.org/10.1086/597175.

Keaveny T., Inderrieden E., Toumanoff P. [2007], Gender Differences in Pay of Young Management Professionals in the United States: A Comprehensive View, ,Journal of Labor Research", vol. 28, nr 2, https://doi.org/10.1007/bf03380049.

Khoreva V. [2011], Gender Pay Gap and Its Perceptions, „Equality, Diversity and Inclusion: An International Journal”, vol. 30, nr 3, https://doi.org/10.1108/02610151111124969.

Kobiety i mężczyźni na rynku pracy [2016], GUS, Warszawa.

Kobiety we władzach spółek giełdowych w Polsce 2016 [2016], Fundacja Liderek Biznesu, Warszawa.

Kram K., Chandler D. [2010], A Self-Directed Approach to Developmental Networks and Leadership Development [w:] Self-Management and Leadership Development, eds M.G. Rothstein, R.J. Burke, Edgar Elgar Publishing, Cheltenham-Northampton.

Kupczyk T. [2009], Kobiety w zarzq̨dzaniu i czynniki ich sukcesów, Wyższa Szkoła Handlowa, Wrocław.

Lisowska E. [2000], Style zarzq̨dzania polskich kobiet menedżerów (w świetle wyników badania ankietowego), ,International Journal of Management and Economics”, nr 8. 
Małżeństwa oraz dzietność w Polsce [2016], GUS, http://stat.gov.pl/obszary-tematyczne/ludnosc/ludnosc/malzenstwa-i-dzietnosc-w-polsce,23,1.html (data dostępu: 30.01.2017).

Manning A., Swaffield J.K. [2008], The Gender Gap in Early-Career Wage Growth, „The Economic Journal”, vol. 118, nr 530, https://doi.org/10.1111/j.1468-0297.2008.02158.x.

McPherson M., Smith-Lovin L., Cook. J. [2001], Birds of a Feather: Homophily in Social Networks, ,Annual Review of Sociology”, vol. 27, nr 1, https://doi.org/10.1146/annurev. soc.27.1.415.

Miller A.R. [2011], The Effects of Motherhood Timing on Career Path, ,Journal of Population Economics", vol. 24, nr 3, https://doi.org/10.1007/s00148-009-0296-X.

Moss-Racusin C.A., Dovidio J.F., Brescoll V.L., Graham M.J., Handelsman J. [2012], Science Faculty's Subtle Gender Biases Favor Male Students, „PNAS”, vol. 109, nr 41, https://doi.org/10.1073/pnas.1211286109.

The Myth of the Ideal Worker: Does Doing All the Right Things Really Get Women Ahead? [2011], Catalyst.

Petersen T., Saporta I., Seidel M.D. [2000], Offering a Job: Meritocracy and Social Networks, ,American Journal of Sociology”, vol. 106, nr 3, https://doi.org/10.1086/318961.

Płeć a możliwości ekonomiczne w Polsce: czy kobiety straciły na transformacji? [2004], Bank Światowy, Departament Walki z Ubóstwem i Zarządzania Gospodarką Region Europy i Azji Środkowej, http://siteresources.worldbank.org/INTPOLAND/Resources/ Gender_report_pl.pdf (data dostępu: 30.01.2017).

Rubery J., Grimshaw D., Figueiredo H. [2005], How to Close the Gender Pay Gap in Europe: Towards the Gender Mainstreaming of Pay Policy, „Industrial Relations Journal", vol. 36, nr 3, https://doi.org/10.1111/j.1468-2338.2005.00353.x.

Sadowska A. [2006], Kobiety w biznesie w Europie, „Studia Ekonomiczne. Zeszyty Naukowe Uniwersytetu Ekonomicznego w Katowicach", nr 37.

The Simple Truth about the Gender Pay Gap [2016], American Association of University Women, http://www.aauw.org/aauw_check/pdf_download/show_pdf.php?file=The-Simple-Truth (data dostępu: 30.01.2017).

Steinpreis R., Anders K.A., Ritzke S. [1999], The Impact of Gender on the Review of the Curricula Vitae of Job Applicants and the Tenure Candidates: A National Empirical Study, ,Sex Roles”, vol. 41, nr 7/8, https://doi.org/10.1023/a:1018839203698.

Szkoły wyższe i ich finanse w 2015 r. [2016], GUS, https://stat.gov.pl/obszary-tematyczne/ edukacja/edukacja/szkoly-wyzsze-i-ich-finanse-w-2015-r-,2,12.html (data dostępu: 30.01.2017).

Yakubovich V. [2005], Weak Ties, Information, and Influence: How Workers Find Jobs in a Local Russian Labor Market, ,American Sociological Review”, vol. 70, nr 3, https:// doi.org/10.1177/000312240507000303.

Yakubovich V., Lup D. [2006], Stages of the Recruitment Process and the Referrer's Performance Effect, „Organization Science”, vol. 17, nr 6, https://doi.org/10.1287/ orsc.1060.0214.

Zarzqdzanie kapitałem ludzkim. Procesy - narzędzia - aplikacje [2014], red. M. Juchnowicz, PWE, Warszawa. 


\section{The Impact of Gender on Supervisors' Perceptions of Employees} (Abstract)

The article examines the impact of gender on how superiors perceive subordinates. The analysis was based on a review of the literature and the results of research on the opinions of subordinates on superiors, done in 2016 by the Institute of Human Capital, Warsaw School of Economics. The causes of pay discrepencies are analysed on the basis of the subject literature, as are the dynamics of women's participation in top positions in Poland and the European Union. The influence a superior may have on an employee's career is characterized. What causes programmes aimed at promoting more objective decisions to be ineffective are identified. Based on the results of quantitative research, gender-based differences in the relationships subordinates have with superiors is determined. A key area of divergence were issues pertaining to justice, particularly where the evaluation of employees, the division of tasks and rewards were concerned.

Keywords: gender pay gap, women in management, mentoring, career opportunities. 